\title{
EDITORIAL
}

\section{POSTGRADUATE MEDICAL EDUCATION (A Contributed Article)}

In a recent editorial about the new specialty of Army Community and Occupational Medicine ${ }^{1}$, this Journal pointed out that Army Medical Officers of all streams are now committed to postgraduate medical training. A comment seems opportune on continuing medical education and training in the other two streams, namely general practice and those specialties based on hospital practice.

For many years before the Royal Commission on Medical Education the Army Medical Services had firm criteria for training and advancement in the specialties, including formal assessments by consultants in charge. Secondments to civil postgraduate centres have been a feature of Army training for more than a quarter of a century. During the 1970 's our programmes of training to consultant status were recognised by the Joint Committees on Higher Training in all of the larger clinical disciplines. The programmes include a year or two of civil secondment.

Visitors assessing military hospital posts for General Professional Training of specialists and for vocational training of General Practitioners set considerable value on the close apprenticeship which the presence of whole-time consultants in small general hospitals allows. The efforts of consultants have been extended by the clinical tutors' weekly programmes of postgraduate education, and recognition of Army posts owes much to the initiative and drive of a succession of Chief Clinical Tutors.

The Army's Group Training Practices run imaginative programmes locally, using the Department of General Practice of the Royal Army Medical College as a resource for ideas and material. All members of the Army Medical Services have access to an enviable reference library service either directly to the Librarian of the Royal Army Medical College or through assistant librarians in larger military hospitals. The installation of a computer terminal for the Librarian of the Royal Army Medical College has further speeded searches of the literature.

The Joint Committee on Postgraduate Training for General Practice has now recognised 25 Army group practices for training purposes and there are at present 33 approved Army trainers. The courses both for trainers and for the MRCGP held at Millbank are widely sought after. A Hunterian lecture of the Royal College of Surgeons of England held at Millbank in 1980, following the Royal College of Surgeons of Edinburgh's meeting there in 1979 illustrates the interest and support received from academic bodies.

What is the challenge for the 1980s? In addition to recognised training, post graduate medical education for all implies an enquiring approach, spiced with rational scepticism towards traditional doctrines and to the voice of experience, in all our professional activities. Support and encouragement for clinical research and for measurement in all military medical fields must be equally certain. It can be argued that for the medical graduates of the 1980s, that this particular professional condition of service will be essential to recruiting.

\section{REFERENCE}

1. Editorial (1979). A new speciality. Journal of the Royal Army Medical Corps. 125, 57. 


\section{JOURNAL STYLE AGAIN}

Over a year ago this Journal ${ }^{1}$ declared an intention of following, as opportunity permitted, in the footsteps of the leading medical contemporaries by requiring all manuscripts to be submitted in the internationally standardized form espoused as the Vancouver Style ${ }^{2}$. This opportunity has now come about and the Journal proposes to come fully into line with the new practice. The conservative reader or author who fears that the Journal is launching unaccompanied into perilous seas of uncharted journalism should consult the recently published list of distinguished medical journals which have declared for Vancouver style standardization ${ }^{3}$.

Hitherto the principal impediment to full adoption of the new style has been the absence of an authorized abbreviation for the title of the Journal; as reported earlier ${ }^{4}$ the Vancouver style requires editors to use only the forms of abbreviation decreed by Index Medicus. At the time this Journal was not cited by Index Medicus and therefore had no recognised abbreviation. This last impediment has now been removed by the happy decision of the Editor of Index Medicus to include the Journal of the Royal Army Medical Corps in the list of cited journals with the consequent allotment of an authorised title abbreviation. Sadly we have not been allowed the brevity and simplicity of our recommended "JRAMC" but have to be content - because machines not men decide the issue for computer indexingwith J R Army Med Corps. Journal title abbreviations are formulated by the rules of the "American National Standard for the Abbreviations of Titles and Periodicals" and individual words have to take the form given in the "Liste d'Abbreviations de Mots des Titres de Periodiques." Instructions for the change will appear in the 'Notice to Authors' of the next issue and it is hoped the transition will be complete for the start of Volume 127.

It should not be thought that the benefits of being listed by Index Medicus are confined to the possession of an abbreviated title. They are far more widespread. Henceforth, by virtue of incorporation into the MEDLINE data base, the Journal's contents will be included in all bibliographic searches. In this way the Journal will receive a much greater measure of national and international recognition. It is an important and significant step forward in the Journal's career.

\section{REFERENCES}

1. Editorial (1979). The Health of the Journal. Journal of the Royal Army Medical Corps. 125, 2-3.

2. International Steering Committee (1979). Uniform Requirements for manuscripts submitted to biomedical journals. Lancet, i, 428-31.

3. Style Matters (1980). List of Participating Journals. British Medical Journal, 280, 23.

4. Editorial (1979). Journal Style. Journal of the Royal Army Medical Corps, 125, 117-118. 